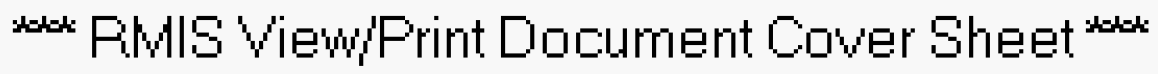

This document was retrieved from the Boeing ISEARCH System.

Accession \#: D196054975

Document \#: SD-WM-ER-510

Title/Desc:

TANK 241U103 HEADSPACE GAS \& VAPOR CHARACTERIZATION REASULTS FOR SAMPLES COLLECTED IN 2/1995 


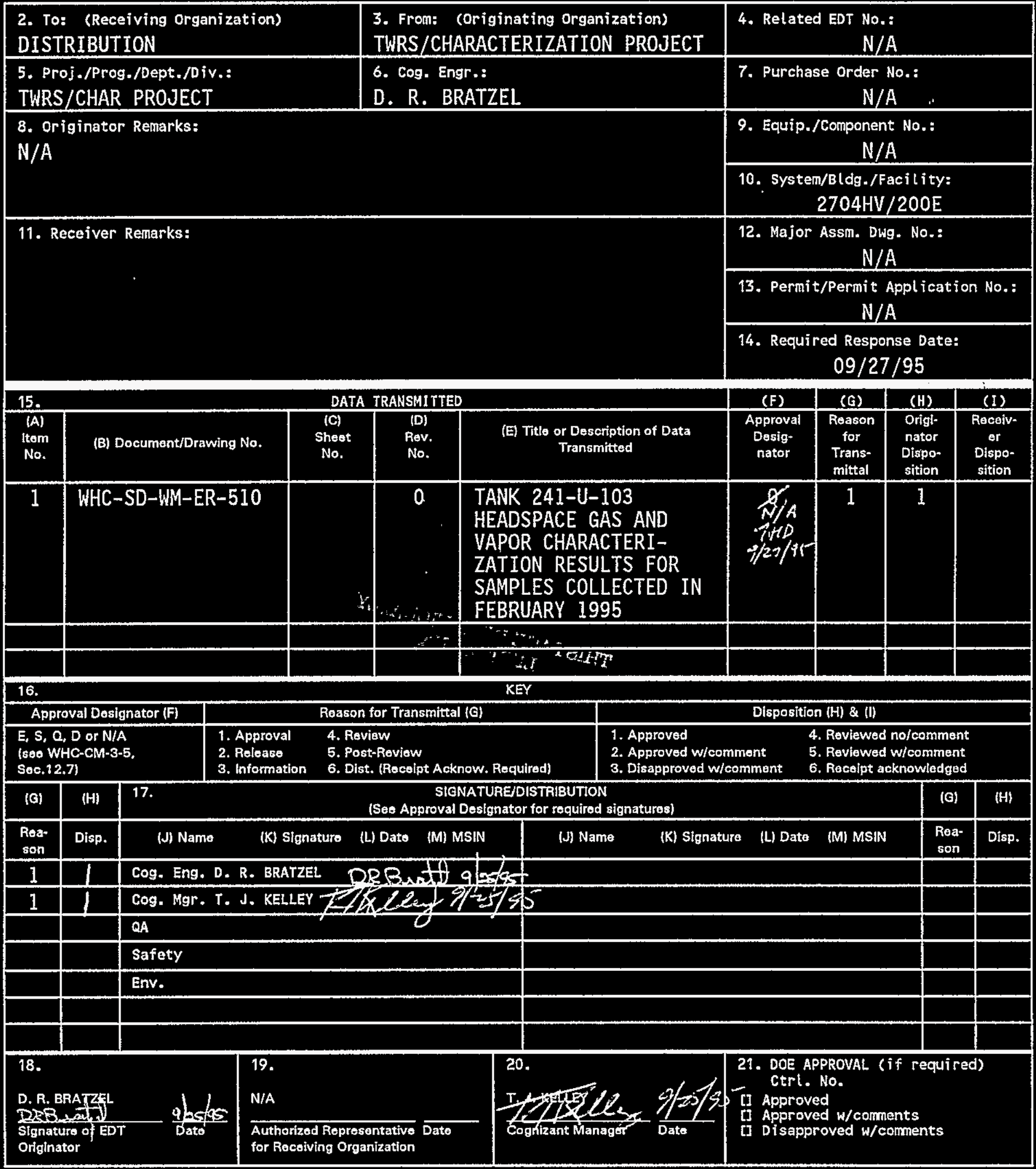

BD-7400-172-2 (04/94) GEF097 


\section{RELEASE AUTHORIZATION}

Document Number: 'WHC-SD-WM-ER-510, REV 0

Tank 241-U-103 Headspace Gas and Vapor

Document Title: $\quad$ Characterization Results for Samples Collected in February 1995

Release Date: $\quad 9 / 27 / 95$

This document was reviewed following the procedures described in WHC-CM-3-4 and is:

APPROVED FOR PUBLIC RELEASE

WHC Information Release Administration Specialist:
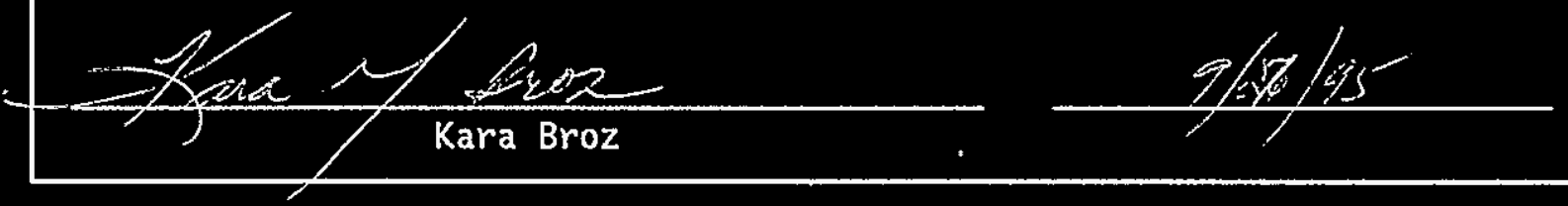

TRADEWARK DISCLAIHER. Reference herein to any specific commercial product, process, or service by trade name, trademark, manufacturer, or otherwise, does not necessarily constitute or imply its endorsement, recommendation, or favoring by the United States Government or any agency thereof or its contractors or subcontractors.

This report has been reproduced from the best available copy. Available in paper copy. Printed in the United States of America. To obtain copies of this report, contact:

Westinghouse Hanford Company - Document Control Services

P.0. Box 1970, Mailstop H6-08, Richland, WA 99352

Telephone: (509) 372-2420; Fax: (509) 376-4989 
2. Title

TANK 241-U-103 HEADSPACE GAS AND VAPOR

CHARACTERIZATION RESULTS FOR SAMPLES COLLECTED IN FEBRUARY 1995

\section{Key words}

CHARACTERIZATION OBJECTIVES, TANK HEADSPACE, SAMPLING EVENT, INORGANIC GASES, ORGANIC VAPORS
3. Nuniber

NHC-SD-NW-ER-510
4. Rev No.

0
6. Author

Name: D. R. BRATZEL.

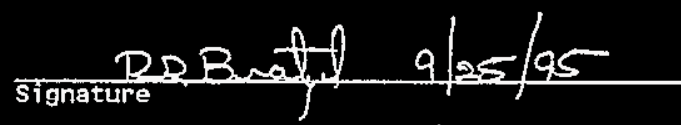

Organization/Charge code

\section{Abstract}

Significant changes have been made to all of the original vapor characterization reports. This report documents specific headspace gas and vapor characterization results for all vapor sampling events to date. In addition, changes have been made to the original vapor reports to qualify the data based on quality assurance issues associated with the performing 1aboratories.

8.
OFELEASE stamp
BYWHAL PHEASE
DATE SEP 271995
Sta 4




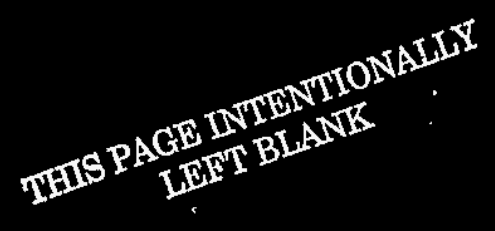




\title{
Tank 241-U-103 Headspace Gas and Vapor Characterization Results for Samples Collected in February 1995
}

\author{
J. L. Huckaby \\ Pacific Northwest Laboratories \\ D. R. Bratzel \\ Westinghouse Hanford Company
}

Date Published

September 1995

Prepared for the U.S. Department of Energy Office of Environmental Restoration and Waste Management

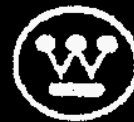

Westinghouse 


\section{TIIS PAGE INTENTIONAIIT}




\section{Contents}

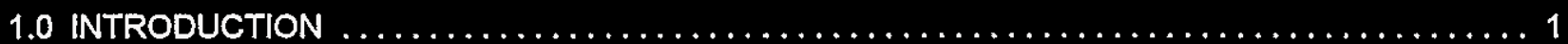

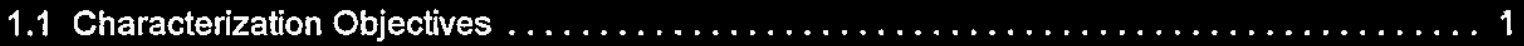

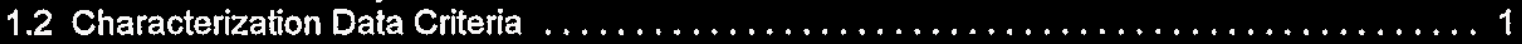

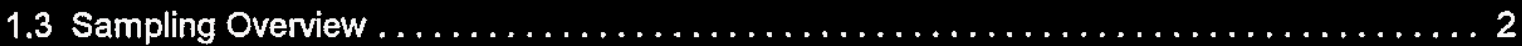

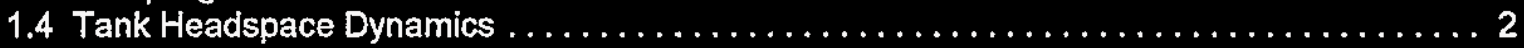

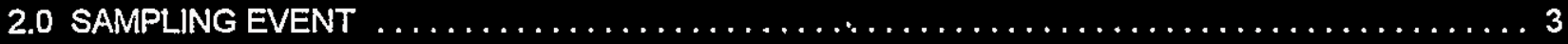

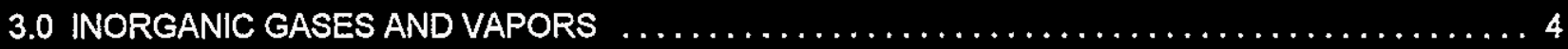

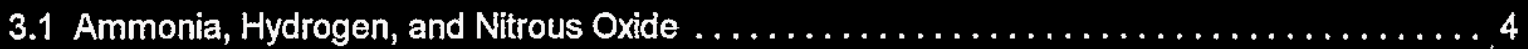

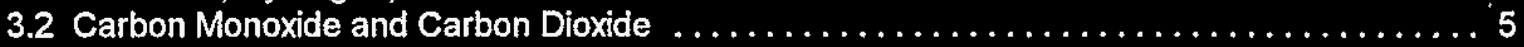

3.3 Nitric Oxide, Nitrogen Dioxide, Water and Tritium $\ldots \ldots \ldots \ldots \ldots \ldots \ldots \ldots \ldots \ldots \ldots$

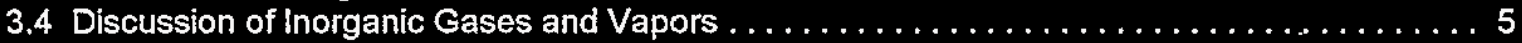

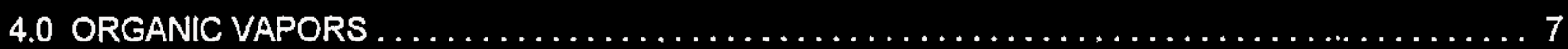

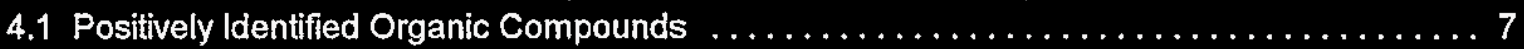

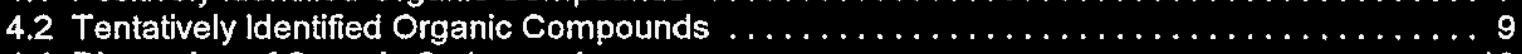

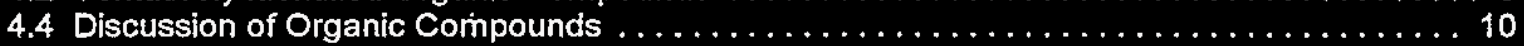

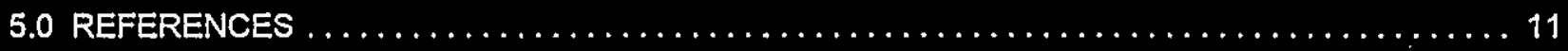

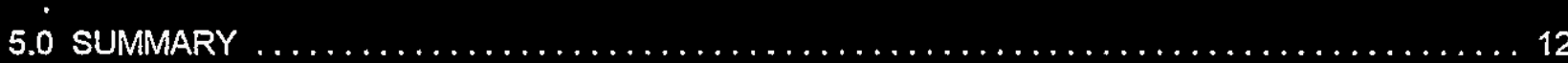

Acronyms and Abbreviàtions

CES

EPA

GC

GCMS .

LFL

MS

NFPA

$\mathrm{NPH}$

ORNL

PNL

ppmv

TNMOC

TST

vol\%

VSS

WHC

$w t \%$ consensus exposure standard

Environmental Protection Agency

gas chromatograph

gas chromatograph/mass spectrometer

lower flammability limit

mass spectrometer

National Fire Protection Association

normal paraffinic hydrocarbon

Oak Ridge National Laboratory

Pacific Northwest Laboratory

parts per million by volume, $1 \mathrm{ppmv}=10^{-4}$ vol $\%$

total nonmethane organic carbon

triple sorbent trap

percent by volume, 1 vol $\%=10,000$ ppmv

vapor sampling system

Westinghouse Hanford Company

percent by weight 


\section{WHC-SD-WM-ER-510 REV. 0}

\section{Acknowledgements}

The author wishes to thank Chris Simonen for her work verifying data and generating tables, and Shas Mattigod for his help with the construction and reviews of this document. 
WHC-SD-WM-ER-510 REV. 0

Tank 241-U-103 Headspace Gas and Vapor Characterization Results

for Samples Collected in February 1995

\subsection{INTRODUCTION}

\subsection{Characterization Objectives}

Tank U-103 headspace gas and vapor samples were collected and analyzed to help determine the potential risks of fugitive emissions to tank farm workers. The drivers and objectives of waste tank headspace sampling and analysis are discussed in Program Plan for the Resolution of Tank Vapor Issues (Osborne and Huckaby 1994). Tank U-103 was vapor sampled in accordance with Data Quality Objectives for Generic In-Tank Health and Safety lssue Resolution (Osborne et al. 1994).

\subsection{Characterization Data Criteria}

Data Quality Objectives for Generic In-Tank Health and Safety Issue Resolution describes parameters for data collection to ensure appropriate conclusions can be drawn from the data. Tank headspace characterization data were collected to help in the evaluation of 1) headspace flammability, and 2) identification and quantification of compounds of toxicological concern.

Single Shell Tank Interim Operational Safety Requirements (Dougherty 1995) specifies that combustible constituents in tank headspaces be maintained below $25 \%$ of the lower flammability limit (LFL). This essentially agrees with National Fire Protection Association requirements that combustible concentrations be maintained at or below $25 \%$ of the LFL. (NFPA 1994). However, current governing operating specifications for single shell watch listed waste tanks, such as tank U-103 specify that combustible constituents be maintained at or below $20 \%$ of the LFL (WHC 1995b).

Headspace characterization data are used by Westinghouse Hanford Company (WHC) Tank Waste Remediation Systems Industrial Hygiene as source term data in the industrial hygiene strategy to protect workers from tank fugitive emissions. Because selection of worker protective equipment must be based on industrial hygiene monitoring of the work place and not on source term data (29 CFR 1910.120), tank headspace characterization data can not be used for this purpose. Furthermore, because there are mechanisms by which headspace constituents can be either diluted or concentrated as they are released to the atmosphere, the headspace characterization data should not be considered to be representative of emissions at the point of emission.

These statements notwithstanding, the data quality objectives document specifies that the industrial hygiene group be advised if constituents with toxicological properties exceed $50 \%$ of the appropriate consensus exposure standard (CES) for non-carcinogens, or $10 \%$ of the appropriate CES for carcinogens. A CES is defined as the most stringent of known regulatory or recommended toxicological values for the workplace (Osborne et al. 1994).

\subsection{Sampling Overview}

Tank headspace characterization data presented here are from a single sampling event. Samples collected are thought to have been representative of the tank U-103 headspace when the tank was sampled, and sample analyses were designed to provide a reasonably accurate and complete 
characterization of the significant headspace constituents (Meacham et al. 1995). No assessment has been made of how the tank U-103 headspace composition changes with time, though studies of tank C-103 suggest that composition changes probably occur very slowly in the passively ventilated tanks (Huckaby and Story 1994).

\subsection{Tank Headspace Dynamics}

Tank U-103 is the third tank in a 3-tank cascade with tanks $U-101$ and $U-102$. It is connected to tank U-102 via a 7.4-cm (2.9-in.) inside diameter, 7.6-m (25-ft) long underground cascade line. A similar line connects tanks $U-101$ and $U-102$. Since these cascade lines connect the headspaces of these tanks, gases and vapors originating from the wastes in tank $U-101$ or tank $U-102$ may be transferred to tank $U-103$ (unless the cascade lines are obstructed). At this time, however, no headspace characterization data are available for tank U-102 to assess their potential transfer of gases and vapors to tank U-103.

The cascade of tanks $U-101, U-102$, and $U-103$ is passively ventilated, which means that the tanks are . allowed to exhale air, waste gases, and vapors as the barometric pressure falls, and inhale ambient air as the barometric pressure rises. Each of these tanks has its own fittered breather riser. Barometric pressure typically rises and falls on a diurnal cycie, producing an average daily exchange of air equal to about $0.46 \%$ of each tank headspace (Huckaby 1994). Changes in the concentrations of tank headspace constituents due to barometric pressure changes are consequently very slow. 


\subsection{SAMPLING EVENT}

Headspace gas and vapor samples were collected from tank U-103 using the vapor sampling system (VSS) on February 15, 1995 by WHC Sampling and Mobile Laboratories (WHC 1995b). Sample collection and analysis were performed as directed by Tank 241-U-103 Tank Characterization Plan (Carpenter 1995). The tank headspace temperature was determined to be $29^{\circ} \mathrm{C}$. Air from the U-103 headspace was withdrawn from a single elevation via a $6.1-\mathrm{m}$ long heated sampling probe mounted in riser 9 , and transferred via heated tubing to the VSS sampling manifold. All heated zones of the VSS were maintained at approximately $60^{\circ} \mathrm{C}$. All tank air samples were collected between 11:03 a.m. and 2:34 p.m., with no anomalies noted.

Sampling media were prepared and analyzed by WHC, Oak Ridge National Laboratories (ORNL), and Pacific Northwest Laboratories (PNL). The 40 tank air samples and 2 ambient air control samples collected are listed in Table 2-1 by analytical laboratory. Table 2-1 also lists the 14 trip blanks and 2 field blanks provided by the laboratories.

A general description of vapor sampling and sample analysis methods is given by Huckaby et al (1995). The sampling equipment, sample coilection sequence, sorbent trap sample air flow rates and flow times, chain of custody information, and a discussion of the sampling event itself are given in WHC (1995b). 


\subsection{INORGANIC GASES AND VAPORS}

Analytical results of sorbent trap and SUMMA ${ }^{T M, 1}$ canister tank air samples for selected inorganic gases and vapors are given in Table 3-1 in parts per million by volume (ppmv) in dry air. The concentration of water vapor given in Table 3-1 has been adjusted to tank conditions and are given in Section 3.3. All inorganic gas and vapor tank samples, ambient air samples, and trip and field blanks were prepared and analyzed by PNL per PNL quality assurance impact level 2 procedures (Ligotke et al. 1995).

PNL analyses of SUMMA ${ }^{T M}$ canisters and sorbent traps for permanent gases and inorganic compounds were performed 30 and 22 days, respectively, after sample collection (Ligotke 1995). Thus these analyses satisfied the 60-day holding time requirement of the WHC quality assurance project plan (Keller 1994). It should be noted that these inorganic compounds (i.e., the permanent gases) would be expected to be very stable in the SUMMA ${ }^{\text {TM }}$ canisters, and the results may not have been affected even if the 60-day holding time requirements had been exceeded.

\subsection{Ammonia, Hydrogen, and Nitrous Oxide}

The reported ammonia concentration from 6 ammonia sorbent trap samples is 730 ppmv. This is relatively high compared to the other passively ventilated tanks that have been vapor sampled. Ammonia has been observed, in virtually all of the passively ventilated waste tanks sampled to date, at concentrations ranging from about 3 ppmv in tank C-108 (Lucke et al. 1995), to 1040 ppmv in BY-108 (McVeety et al. 1995). Given the LFL of ammonia in air is about $15 \%$ by volume (vol\%), the measured 730 ppmv corresponds to less than $0.5 \%$ of the LFL, and does not contribute appreciably to the flammability of the headspace.

The concentration of hydrogen in tank U-103 was determined to be 555 ppmv. Hydrogen in the waste tanks is of concern as a fuel. Given that the LFL for hydrogen in air is about 4 vol\%, 555 ppmv hydrogen concentration in tank U-103 corresponds to about $1.4 \%$ of its LFL. At this level, hydrogen is not a flammability concern in tank U-103.

The nitrous oxide concentration in tank U-103, $878 \mathrm{ppmv}$, is the highest measured in any passively ventilated tank that has been sampled. Nitrous oxide has been detected in other passively ventilated waste tanks at average concentrations as low as about 12 ppmv in tank TX-105 (Klinger et al.1995), and as high as [763 ppmv] in tank C-1032 (Huckaby and Story 1994). Under proper conditions, nitrous oxide can serve as an oxidizer to support combustion. However, Cashdollar et al. (1992) found that nitrous oxide had no significant effect on the flammability of hydrogen and air mixtures for hydrogen concentrations less than 20 vol\%, and that "small amounts of nitrous oxide (relative to air) do not appear to have much effect on the flammability". Their results suggest the measured nitrous oxide concentration is much too low to have a significant effect on the flammability of the tank U-103 headspace.

\subsection{Carbon Monoxide and Carbon Dioxide}

Carbon monoxide in the tank U-103 headspace was measured in each of the 3 SUMMA ${ }^{\mathrm{TM}}$ canister samples to be $<12 \mathrm{ppmv}$. In ambient air it typically ranges from 0.05 to $0.15 \mathrm{ppmv}$. Because different analytical methods have been used to measure carbon monoxide in the waste tanks sampled to date, the information

1 SUMMA is a trademark of Molectrics, Inc., Cleveland, Ohio.

${ }^{2}$ The carbon monoxide measurement in tank $\mathrm{C}-103$ was made by Oregon Graduate Institute of Science and Technology, and have been placed in brackets to indicate it should be considered secondary data. 
on carbon monoxide has varied from tank to tank. However, in waste tank headspace elevated carbon monoxide concentrations are common, and are thought to be due to the decomposition of organic waste in the tanks. Carbon monoxide has not been measured at very high levels in any of the waste tanks, the highest level measured to date was [26.7 ppmv] in tank C-103 (Huckaby and Story 1994).

The carbon dioxide concentration in the tank U-103 headspace, reported as $<64$ ppmv, is significantly - lower than it is in ambient air. Carbon dioxide introduced by air exchange with the atmosphere is readily absorbed by caustic supernatant and interstitial liquids in the waste tanks, and converted to carbonate in solution. Carbon dioxide is normally present in the ambient air at a concentration of 350 to 400 ppmv, and is typicaily lower than ambient in the waste tank headspaces. The 2 ambient air samples collected at the start of the tank U-103 gas and vapor sampling event, for example, were measured to have an average 364 ppmv of carbon dioxide. Because different analytical methods have been used to measure carbon dioxide in the waste tank samples, the information on carbon dioxide varies. The $<64 \mathrm{ppmv}$ of carbon dioxide characterization of the tank U-103 headspace is typical of that found in other passively ventilate tanks that have been sampled.

\subsection{Nitric Oxide, Nitrogen Dioxide, Water and Tritium}

Nitric oxide and nitrogen dioxide concentrations in the tank U-103 headspace were determined to be 50.03 and $\leq 0.02$ ppmv, respectively. These are acid gases that would have very low equilibrium concentrations above the high pH sludge in tank U-103. The measurable presence of nitric oxide is not uncommon in the waste tank headspaces, and may be due to its formation from oxygen and nitrogen in the radiation field of the headspace. These constituents could potentially serve as oxidizers to support combustion, but at the measured concentrations would have a negligible effect on the flammability of the tank U-103 headspace.

The water vapor concentration of tank U-103 was determined to be about $12.2 \mathrm{mg} / \mathrm{L}$, at the measured tank headspace temperature of $29^{\circ} \mathrm{C}$ and pressure of $982 \mathrm{mbar}$ (736.8 torr), (WHC 1995b). This corresponds to a water vapor partial pressure of $16.9 \mathrm{mbar}(12.7 \mathrm{torr})$, to a dew point of $14.9^{\circ} \mathrm{C}$, and to a relative humidity of $42 \%$.

Silica gel sorbent traps were used to test for tritium. It is assumed that tritium produced by the waste combines with hydroxide ions to form tritium-substituted water. Evaporation of the tritium-substituted water would then result in airborne radioactive contamination. Silica gel sorbent traps adsorb virtually all (normal and tritium-substituted) water vapor from the sampled tank air, and are analyzed at the WHC 222-S laboratory. Radiochemical analysis of the silica gel trap indicated the total activity of the headspace to be less than $50 \mathrm{pCi} / \mathrm{L}$ (WHC 1995b).

\subsection{Discussion of Inorganic Gases and Vapors}

Aside from water vapor, the most abundant waste constituents in the tank $\mathrm{U}-103$ headspace are nitrous oxide, ammonia, and hydrogen. These have been detected in most tank headspaces sampled to date, and are usually the dominant gas species. These 3 species are each at higher than average concentrations in tank U-103.

The relative standard deviations of the inorganic gas and vapor results given in the last column in Table 3-1 are excellent for the methods used. Relative standard deviations range from about $0.5 \%$ for hydrogen to about $4.4 \%$ for water vapor. Because the precision reported depends both on sampling parameters (e.g.,

\footnotetext{
${ }^{3}$ See preceding footnote.
} 
WHC-SD-WM-ER-510 REV. 0

sample flow rate and flow time for sorbent traps) and analytical parameters (e.g., sample preparation, dilutions, etc.), small relative standard deviations suggest proper control was maintained both in the field and in the laboratories. 


\subsection{ORGANIC VAPORS}

Organic vapors in the tank U-103 headspace were sampled using SUMMA ${ }^{\text {TM }}$ canisters, which were analyzed by PNL, and triple sorbent traps (TSTs), which were analyzed by ORNL. PNL and ORNL both used a gas chromatograph (GC) equipped with a mass spectrometer (MS) detector to separate, identify, and quantitate the anaiytes. Descriptions of sample device cleaning, sample preparations, and analyses are given by Jenkins et al. (1995a) and Ligotke et al. (1995).

SUMMA'M sample results should be considered to be the primary organic vapor data for tank U-103. These results were produced at PNL quality assurance impact level 2. All analyses were completed 69 days after sample collection, thus exceeding by 9 days the administratively chosen 60-day holding time limit (Keller 1994). No hoiding time study has been done to determine the stability of organic compounds in SUMMA ${ }^{\text {TM }}$ canisters in the typical chemical matrix of the waste tank samples.

ORNL analyses of TST samples from this and other waste tanks generally agree with, support, and augment the SUMMA ${ }^{T M}$ sample results. However, because certain WHC quality assurance requirements were not satisfied by ORNL, the quality assurance assessment of ORNL by Hendrickson (1995) should be reviewed before results unique to the TST samples are used for decision making.

ORNL analyzed 3 of the 12 TST tank samples, 1 of the 2 TST field blanks, and 1 of the 2 TST trip blanks. Of the 12 TST tank samples, 4 were collected with sample volumes of about $0.2 \mathrm{~L}$, 4 with volumes of about $1.0 \mathrm{~L}$, and 4 with volumes of about $4.0 \mathrm{~L}$. Based on the observed amounts of organic vapors trapped by one of the $1.0 \mathrm{~L}$ sample volume TSTs, ORNL determined that the best results would be obtained from the $1.0 \mathrm{~L}$ samples. The $1.0 \mathrm{~L}$ samples were analyzed in triplicate, and the remaining $1.0 \mathrm{~L}$ sample was archived.

All TSTs prepared by ORNL had 3 surrogate compounds added to evaluate sampie matrix effects, potential handling, storage, and shipment problems, and analytical instrumentation performance (Jenkins et al. 1995a). ORNL evaluated the surrogate recoveries using a statistical approach similar to that prescribed by SW 846 Method 8260A Volatile Organic Compounds by Gas Chromatography/Mass Spectrometry (GCMS) Capillary Column Technique (EPA 1992). Using this approach, ORNL reported that all surrogates had standard deviation values within the $95 \%$ confidence interval for variance, indicating that no bias was introduced in the measurement of analyte quantities (Jenkins 1995a).

\subsection{Positively Identified Organic Compounds}

Positive identification of organic analytes using the methods employed by PNL and ORNL involves matching the GC retention times and MS data from a sample with that obtained from the analysis of standards. The concentration of an analyte in the sample is said to be quantitatively measured if the response of the GC/MS has been established at several known concentrations of that analyte (l.e., the GCMS has been calibrated for that analyte), and the MS response to the analyte in the sample is between the lowest and highest responses to the known concentrations (i.e., the analyte is within the calibration range).

ORNL and PNL were assigned different lists of organic compounds, or target analytes, to positively identify and measure quantitatively. The ORNL target analyte list was derived from a review of the tank C-103 headspace constituents by a panel of toxicology experts (Mahlum et al. 1994). The PNL target analyte list included 39 compounds in the Environmental Protection Agency (EPA) task order 14 (TO-14) method, which are primarily halocarbons and common industrial solvents (EPA 1988), plus 14 analytes selected mainly from the toxicology panel's review of vapor data from tank C-103. 
Table 4-1 lists the organic compounds positively identified and quantitated in SUMMA ${ }^{\mathrm{TM}}$ samples by PNL. SUMMA ${ }^{\mathrm{TM}}$ analyses were performed according to the TO-14 methodology, except for methane analysis, which was analyzed with the inorganic gases (Ligotke et al. 1995). Only 4 of the 39 TO-14 target anaiytes and 7 of the 14 additional target analytes were measured to be above the 0.005 ppmv detection limit of the analyses. Averages reported are from analyses of 3 SUMMA ${ }^{T M}$ canister samples.

Jenkins et al. (1995a) report the positive identification of 24 of 27 target analytes in TST samples. 1,1Dichloroethene, butanal, and dibutyl butylphosphonate were the only TST target anaiytes not detected. ORNL reported the positive identification of tributyl phosphate, but it was not quantitatively measured. The tributyl phosphate concentration was estimated to be less than $0.0001 \mathrm{ppmv}$. The average concentrations of the 7 quantified target anaiytes, from the analysis of 3 TSTs, are given in Table 4-2. Table 4-3 lists the 14 positively identified analytes for which at least 1 sample result was outside the instrument calibration range, and consequently not quantitatively measured. Table 4-4 lists 2 analytes determined to have exceeded their ORNL practical holding times (Jenkins 1995b). Tables 4-2, 4-3, and 4-4 are mutually exclusive, so that no analyte appears in more than 1 of these tables. Data in Tables 4-3 and 4-4 should not be considered quantitative and may not be accurate within $\pm 30 \%$ as specified by Burnum (1995).

The ORNL practical holding time is defined as the holding time for which there is a $15 \%$ risk that the concentration of an analyte in the sample will be below its initial concentration. Jenkins et al. (1995b) describe the ORNL practical holding time study, and report the practical holding times of butanal, 1 -butanol, and 2-pentanone are 1, 17, and 34 days, respectively. Because TST analyses were not completed until 37 days after sample collection (Jenkins 1995b), the results for these 3 compounds may have been affected. It is possible that 2-pentanone was not identified in the tank U-103 TST samples because the practical holding time for this compound was exceeded. It should also be noted that the contractual holding time for the TST samples was 60 days.

Analysis of the TST field and trip blanks by ORNL indicated both types of TSTs were contaminated with the ORNL target analytes. In particular, the trip blank TST was determined to have very small amounts of propanone, $n$-dodecane, and $n$-tridecane, and small amounts of dichloromethane and trichlorofluoromethane. The field blank was determined to have very small amounts of dichloromethane, benzene, $n$-undecane, n-dodecane, $n$-tridecane, and 2,2,3-trimethyidecane. The field blank also had a moderate amount of 5-octadecene. No adjustment of the ORNL results has been made to account for these observations.

Both PNL and ORNL report target analyte concentrations in ppmv of analyte in dry air. To correct for the measured water vapor content of tank U-103 and obtain concentration in ppmv of analyte in moist tank air, multiply the dry-air ppmv concentrations by 0.983 .

Eleven target analytes were common to both TST and SUMMA ${ }^{T M}$ analyses. Table 4-5 lists these, and their reported average concentrations in TST and SUMMA'TM samples. Results from these 2 sampling and analytical methods are in good agreement for propanone, propanenitrile, benzene, and toluene. As indicated in Table 4-5, ORNL reported concentrations of dichloromethane, $n$-butanenitrile, $n$-hexane, and nheptane in TST samples are moderately higher than the SUMMA ${ }^{\text {TM }}$ sample analytical detection limit, yet were not reported as being present in the SUMMA ${ }^{T M}$ samples.

The largest discrepancy between the target analyte results from the 2 methods is for ethanenitrile, which was determined to be present at 0.16 ppmv in TST samples, and 0.012 ppmv in SUMMA ${ }^{\text {TM }}$ samples. Except for propanenitrile, the nitriles are generally found to be higher in TST than in SUMMATM samples. This may be due to a variety of problems, such as poor analytical recovery of nitriles from SUMMA ${ }^{\text {TM }}$ samples. 
The most abundant analytes in Tables 4-1 through 4-4 are 1-butanol, ethanenitrile, and propanone, each of which was measured to have an average concentration of between 0.1 and 1 ppmv. At the reported concentrations, the target analytes do not individually or collectively represent a flammability hazard.

\subsection{Tentatively Identified Organic Compounds}

In addition to the target analytes, the ORNL and PNL analytical procedures allow the tentative identification of other organic compounds. Tentative identification of analytes was performed by comparing the MS molecular fragmentation patterns with a library of known MS fragmentation patterns. This method allows an organic analyte to be identified (with reasonable certainty) as an alkane, a ketone, an aldehyde, etc., and may also determine its molecular weight. The method usually does not, however, allow the unambiguous identification of structural isomers, and this ambiguity increases with analyte molecular weight. Using this method, many analytes can be tentatively identified with reasonable confidence without having to inject standards of each into the GC/MS to determine their GC retention times or specific MS patterns.

By the nature of the sampling devices, virtually all organic vapors present in the tank headspace are collected by both TST and SUMMA ${ }^{\mathrm{TM}}$ samples. Analyses of the samples are designed to recover, separate, and identify the organic vapors in the samples. TSTs are not good for collecting highly volatile compounds (i.e., molecules more volatile than propane), but are quite good for most others. In contrast, the recovery of very low volatility compounds (e.g., molecules with more than about 15 carbon atoms) and some polar compounds with moderate volatility (e.g., butanal) from SUMMA ${ }^{\mathrm{TM}}$ samples has been problematic.

The list of tentatively identified compounds recovered from SUMMA ${ }^{\mathrm{TM}}$ samples, with estimated concentrations, is given in Table 4-6. Compounds are listed in Table 4-6 in order of decreasing estimated concentration. The list of tentatively identified compounds detected in TST samples, and their estimated concentrations, is given in Table 4-7. Compounds are listed in Table 4-7 in according to the order by which they eluted chromatographically. The averages reported by ORNL in Table 4-7 are all 3-sample averages, and if an analyte was not detected in a sample, its concentration in that sample was considered to be zero for averaging purposes. Estimated concentrations are in $\mathrm{mg} / \mathrm{m}^{3}$, based on dry air at $0^{\circ} \mathrm{C}$ and 1.01 bar.

Because the list of tentatively identified organic compounds in TST samples is rather long and locating any given compound may be difficult, the list has been sorted both alphanumerically by compound name and is given Table 4-8. Similarly, Table 4-9 lists the compounds tentatively identified in TST samples in order of decreasing estimated concentrations. Numbers in the first columns of Tables 4-8 and 4-9 (Cmpd \#) identify the location of the compound in Table 4-7.

The ORNL and PNL methods used to tentatively identify and estimate concentrations are described by Jenkins et al. (1995a) and Ligotke et al. (1995), respectively, and should be reviewed before this data are used for decision making. Concentrations given in Tables 4-6 and 4-7 should be considered rough estimates.

\subsection{Discussion of Organic Compounds}

A convenient way to consider the organic compounds listed in Tables 4-1 through 4-9 is to separate them into 2 categories: 1) Organic compounds added to tank $U-103$ as waste that are still evaporating; and 2) organic compounds that have been generated by reactions of the original waste.

Organic vapors in the first category (those that were placed into the tank as waste) include the semivolatile straight-chain alkanes, which were used as diluents of tributyl phosphate in various plutonium extraction 
processes. These alkanes (i.e., $n$-undecane, $n$-dodecane, $n$-tridecane, and $n$-tetradecane) are often referred to in Hanford site literature as the normal parafinic hydrocarbons (NPHs). Though NPHs are positively identified in tank U-103, their concentrations in tank U-103 are very low compared to other NPHrich tanks.

Tributyl phosphate is also in the category of compounds added as waste. The estimated $\leq 0.0001 \mathrm{ppmv}$ of tributyl phosphate detected in TST samples by ORNL may not be representative of its headspace concentration. Informal tests by ORNL indicate that tributyl phosphate is adsorbed by the glass fiber filters used during sampling to protect the samples from radiolytic particulate contamination. This would result in loss of tributyl phosphate from the sampled air, and an underestimation of its actual concentration in the tank headspace. The presence of the NPHs, which were used as tributyl phosphate process diluents, and the relative abundance of 1-butanol, a known hydrolysis product of tributyl phosphate, suggest that there are small amounts of tributyl phosphate in tank U-103 waste.

The second category includes all organic compounds that have been generated via radiolytic and chemical reactions of the waste. The majority of compounds listed in Tables 4-1 through 4-9 fall into this category, including the alcohols, aldehydes, ketones, nitriles, and volatile alkanes, all of which have been associated with the degradation of the NPHs.

Though not present in high concentrations, 9 alkyl nitriles were identified in TST samples. Many nitrogencontaining cyclic compounds were also detected in TST samples, including pyridines, pyrazines, pyrazoles, and oxazoles.

On the basis of concentrations, alcohols are the dominant type of organic compounds in the tank U-103 headspace. The volatile alcohols methanol, ethanol, 1-propanol, and 2-propanol account for about $35 \%$ by weight (wt\%) of the total estimated concentration of organic compounds in TST samples. Similarly, methanol, ethanol, and 1-propanol account for about $49 \mathrm{wt} \%$ of the total estimated organic compound concentration in SUMMA ${ }^{\mathrm{TM}}$ samples. The abundance of volatile alcohols is similar to that found in tanks $U$ $105, \mathrm{U}-106, \mathrm{U}-107$, and $\mathrm{U}-111$. Also similar to these other $241-\mathrm{U}$ farm tanks, and in contrast to tanks having higher NPH concentrations, tank $U-103$ has relatively few aldehydes.

Ambient air SUMMA ${ }^{\mathrm{TM}}$ samples collected during the tank U-103 sampling event indicated low levels of propanone (i.e., 0.008 and $0.023 \mathrm{ppmv}$ ) and ethanenitrile ( 0.11 to $0.21 \mathrm{ppmv}$ ) in the ambient air. Methanol was also detected in the ambient air sample collected via the VSS manifold, but not when ambient air was sampled directly. This suggests that trace amounts of methanol may have existed in the VSS manifold, even after it was heated and purged with ambient air for $30 \mathrm{~min}$. The reported concentration of methanol in the ambient air sample collected via the VSS manifold, $0.12 \mathrm{ppmv}$, was small compared to the estimated tank U-103 methanol concentration of 2.2 ppmv.

The total organic vapor concentration of tank U-103 was estimated by Jenkins et al. (1995a) to be about 7.2 $\mathrm{mg} / \mathrm{m}^{3}$ from the analysis of 3 TST samples by GC/MS. A similar summation of organic compounds measured in SUMMA ${ }^{T M}$ samples from tank U-103 provides an estimated total organic vapor concentration of $11 \mathrm{mg} / \mathrm{m}^{3}$. This disagreement is largely due to the different estimated concentrations of the dominant alcohols in the 2 sample typés.

In summary, the types and concentrations of organic vapors in tank U-103 are similar to those of other 241$U$ farm tanks. The organic vapors in tank U-103 indicate the presence of tributyl phosphate, the semivolatile NPHs and their degradation products in the tank waste. As with the other 241-U farm tanks sampled to date, the concentrations of short-chain alcohols are higher in tank U-103 than in waste tanks with higher NPH vapor concentrations. Conversely, aldehydes are less abundant in tank U-103 than in NPH-rich waste tanks. 


\subsection{SUMMARY}

The tank U-103 headspace was sampled in February 1995 for gases and vapors to address flammability and industrial hygiene concerns. Collection and analysis of samples has been reported. However, the measured ammonia concentration of 730 ppmv does exceed the industrial hygiene notification limit of 150 ppmv. It was determined that no other headspace constituents exceeded the flammability or industrial hygiene notification limits specified in the current Vapor Sampling and Analysis Plan (Homi 1995). 
THIS PAGE INTENTIONALIY

\author{
IEITT BLANK
}




\section{WHC-SD-WM-ER-510 REV. 0}

\subsection{REFERENCES}

29 CFR 1910.120, 1993, "Hazardous Waste Operations and Emergency Response", Code of Federal Regulations.

Burnum, S.T., 1995, Qualification of Reported WHC Vapor Program Data, (letter 95-CHD-065 to president, - Westinghouse Hanford Company, August 18), Department of Energy, Richland Operations Office, Richland, Washington.

Carpenter, B. C., 1995, Tank 241-U-103 Tank Characterization Plan, WHC-SD-WM-TP-288, Westinghouse Hanford Company, Richland, Washington.

Cashdollar, K. L.,,M. Hertzberg, I. A. Zlochower, C. E. Lucci, G. M. Green, and R. A. Thomas, 1992, Laboratory Flammability Studies of Mixtures of Hydrogen, Nitrous Oxide, and Air, WHC-SD-WMES-219 Rev. 0, Westinghouse Hanford Company, Richland, Washington.

Dougherty, L. F., 1995, Single Shell Tank Interim Operational Safety Requirements, WHC-SD-WM-OSR005 Rev. 0, Westinghouse Hanford Company, Richland, Washington.

EPA 1988, Compendium of Methods for the Determination of Toxic Organic Compounds in Ambient Air, PB90-127374, U.S. Environmental Protection Agency, Washington, D.C.

EPA 1992, Test Methods for Evaluating Solid Waste, SW 846 Rev. 1, U.S. Environmental Protection Agency, Washington, D.C.

Hendrickson, R. W., 1995, Tank Vapor Characterization Oak Ridge National Laboratories Quality Assurance Assessment, TWRSQA-95-0012, Westinghouse Hanford Company, Richland, Washington.

Huckaby, J. L., 1994, Tank 241-C-103 Headspace Flammability, WHC-EP-0734 Rev. 1, Westinghouse Hanford Company, Richland, Washington.

Huckaby, J. L., and H. Babad, 1995, Waste Tank Headspace Gas and Vapor Characterization Reference Guide, WHC-SD-WM-ER-430 Rev. 0, Westinghouse Hanford Company, Richland, Washington.

Huckaby, J. L., and M. S. Story, 1994, Vapor Characterization of Tank 241-C-103, WHC-EP-0780 Rev. 0, Westinghouse Hanford Company, Richiand, Washington.

Jenkins, R. A., 1995a, Untitled, (letter 090195A to D. Bratzel, September 1), Oak Ridge National Laboratory, Oak Ridge, Tennessee.

Jenkins, R. A., 1995b, Untitled, (letter 091495A to D. Bratzel, September 14), Oak Ridge National Laboratory, Oak Ridge, Tennessee.

Jenkins, R. A, A. B. Dindal, C. Y. Ma, M. A. Palausky, J. T. Skeen, and C. K. Bayne, 1995a, Analysis of Tank 241-U-103 Headspace Components, ORNL-CASD-FR-241U103.95 Rev. 0, Oak Ridge National Laboratory, Oak Ridge, Tennessee.

Jenkins, R. A, A. B. Dindal, C. Y. Ma, M. A. Palausky, J. T. Skeen, and C. K. Bayne, 1995b, Analysis of Tank 241-TY-104 Headspace Components, ORNL-CASD-FR-241TY104.95 Rev. 1, Oak Ridge National Laboratory, Oak Ridge, Tennessee. 


\section{WHC-SD-WM-ER-510 REV. 0}

Keller, K.K., 1994 Quality Assurance Project Plan for Tank Vapor Characterization, WHC-SD-WM-QAPP013 Rev.2, Westinghouse Hanford Company, Richland, Washington.

Klinger, G. S., T. W. Clauss, M. W. Ligotke, K. H. Pool, R. B. Lucke, B. D. McVeety, O. P. Bredt, J. S. Young, M. McCulloch, J. S. Fruchter, and S. C. Goheen; 1995, Vapor Space Characterization of Waste Tank 241-TX-105: Results from Samples Collected Through the Vapor Sampling System on 12/20/94, PNL-10594 UC-606, Pacific Northwest Laboratory, Richland, Washington.

Ligotke, M. W., 1995, PNL Vapor Project Analytical Holding Times, (Letter to D.R. Bratzel, September 23, 1995), Pacific Northwest Laboratories, Richland, Washington.

Ligotke, M. W., K. H. Pool, T. W. Clauss, B. D. MoVeety, G. S. Klinger, K. B. Olsen, O. P. Bredt, J. S. Fruchter, and S. C. Goheen, 1995, Vapor Space Characterization of Waste Tank 241-U-103: Results from Samples Collected on 2/15/95, PNL-10813 UC-606, Pacific Northwest Laboratory, Richland, Washington.

Lucke, R. B., M. W. Ligotke, K. H. Pool, T. W. Clauss, A. K. Sharma, B. D. MoVeety, M. McCulloch, J. S. Fruchter, and S. C. Goheen, 1995, Vapor Space Characterization of Waste Tank 241-C-108: Results from Samples Collected Through the Vapor Sampling System on 8/5/94, PNL-10351 UC606 , Pacific Northwest Laboratory, Richland, Washington.

Mahlum, D. D., J. Y. Young, and R. E. Weller, 1994, Toxicologic Evaluation of Analytes from Tank 231-C103, PNL-10189, Pacific Northwest Laboratory, Richland, Washington.

McVeety, B. D., T. W. Clauss, M. W. Ligotke, K. H. Pool, R. B. Lucke, G. S. Klinger, J. S. Young, M. McCulloch, J. S. Fruchter, and S. C. Goheen, 1995, Vapor Space Characterization of Waste Tank 241-BY-108: Results from Samples Collected on 10/27/94, PNL-10495 UC-606, Pacific Northwest Laboratory, Richland, Washington.

Meacham, J. E., H. Babad, R. J. Cash, G. T. Dukelow, S. J. Eberlein, D. W. Hamilton, G. D. Johnson, J. W. Osborne, M. A. Payne, D. J. Sherwood, D. A. Turner, and J. L. Huckaby, 1995, Approach for Tank Safety Characterization of Hanford Site Waste, WHC-EP-0843, Westinghouse Hanford Company, Richland, Washington.

NFPA 1992, Standard on Explosion Prevention Systems, NFPA 69, National Fire Protection Association, Quincy, Massachusetts

Osborne, J. W., and J. L. Huckaby, 1994, Program Plan for the Resolution of Tank Vapor /ssues, WHC-EP0562 Rev. 1, Westinghouse Hanford Company, Richland, Washington.

Osborne, J. W., J. L. Huckaby, T. P. Rudolph, E. R. Hewitt, D. D. Mahlum, J. Y. Young, and C. M. Anderson, 1994, Data Quality Objectives for Generic In-Tank Health and Safety Issue Resolution, WHC-SD-WM-DQO-002, Westinghouse Hanford Company, Richland, Washington.

WHC 1995a, Vapor and Gas Sampling of Single-Shell Tank 241-U-103 Using the Vapor Sampling System, WHC-SD-WM-RPT-149, Westinghouse Hanford Company, Richland, Washington.

WHC 1995b, Operating Speciilications for Watchlist Tanks, OSD-T-151-00030, Rev. B-9, Westinghouse Hanford Company, Richland, Washington 
WHC-SD-WM-ER-510 REV. 0

Table 2-1

Tank U-103 Gas and Vapor Sample Type and Number

\begin{tabular}{|c|c|c|c|c|}
\hline Laboratory & Sampling Device & $\begin{array}{c}\text { Nominal Sample } \\
\text { Volume (L) }\end{array}$ & Target Analytes & Number of Samples \\
\hline $\begin{array}{l}\text { Oak Ridge National } \\
\text { Laboratories }\end{array}$ & Triple Sorbent Trap & $\begin{array}{l}0.2 \\
1.0 \\
4.0\end{array}$ & $\begin{array}{l}\text { Organic vapors } \\
\text { Organic vapors } \\
\text { Organic vapors }\end{array}$ & $\begin{array}{l}4 \text { tank air samples } \\
4 \text { tank air samples } \\
4 \text { tank air samples } \\
+2 \text { trip blanks } \\
+2 \text { field blanks }\end{array}$ \\
\hline \multirow[t]{4}{*}{$\begin{array}{l}\text { Pacific Northwest } \\
\text { Laboratories }\end{array}$} & $\begin{array}{l}\text { Acidified Carbon Sorbent } \\
\text { Trap }\end{array}$ & 3.0 & Ammonia & $\begin{array}{l}6 \text { tank air samples } \\
+3 \text { trip blank }\end{array}$ \\
\hline & $\begin{array}{l}\text { Triethanolamine Sorbent } \\
\text { Trap }\end{array}$ & 3.0 & Nitrogen Dioxide & $\begin{array}{l}6 \text { tank air samples } \\
\text { + } 3 \text { trip blank }\end{array}$ \\
\hline & $\begin{array}{l}\text { Oxidation Bed }+ \\
\text { Triethanolamine Sorbent } \\
\text { Trap }\end{array}$ & 3.0 & Nitric Oxide & $\begin{array}{l}6 \text { tank air samples } \\
\text { + } 3 \text { trip blank }\end{array}$ \\
\hline & Silica Gel Sorbent Trap & 3.0 & Water vapor & $\begin{array}{l}6 \text { tank air samples } \\
\text { + } 3 \text { trip blanks }\end{array}$ \\
\hline · & SUMMA ${ }^{T M}$ canister & 6.0 & $\begin{array}{l}\text { Carbon Dioxide, } \\
\text { Carbon Monoxide, } \\
\text { Hydrogen, Methane, } \\
\text { Nitrous Oxide, Organic } \\
\text { vapors }\end{array}$ & $\begin{array}{l}3 \text { tank air samples }+2 \\
\text { ambient air samples }\end{array}$ \\
\hline WHC 222-S Laboratory & Silica Gel Sorbent Trap & 1.0 & $\begin{array}{l}\text { Tritium-Substituted Water } \\
\text { Vapor }\end{array}$ & 1 tank air sample \\
\hline
\end{tabular}




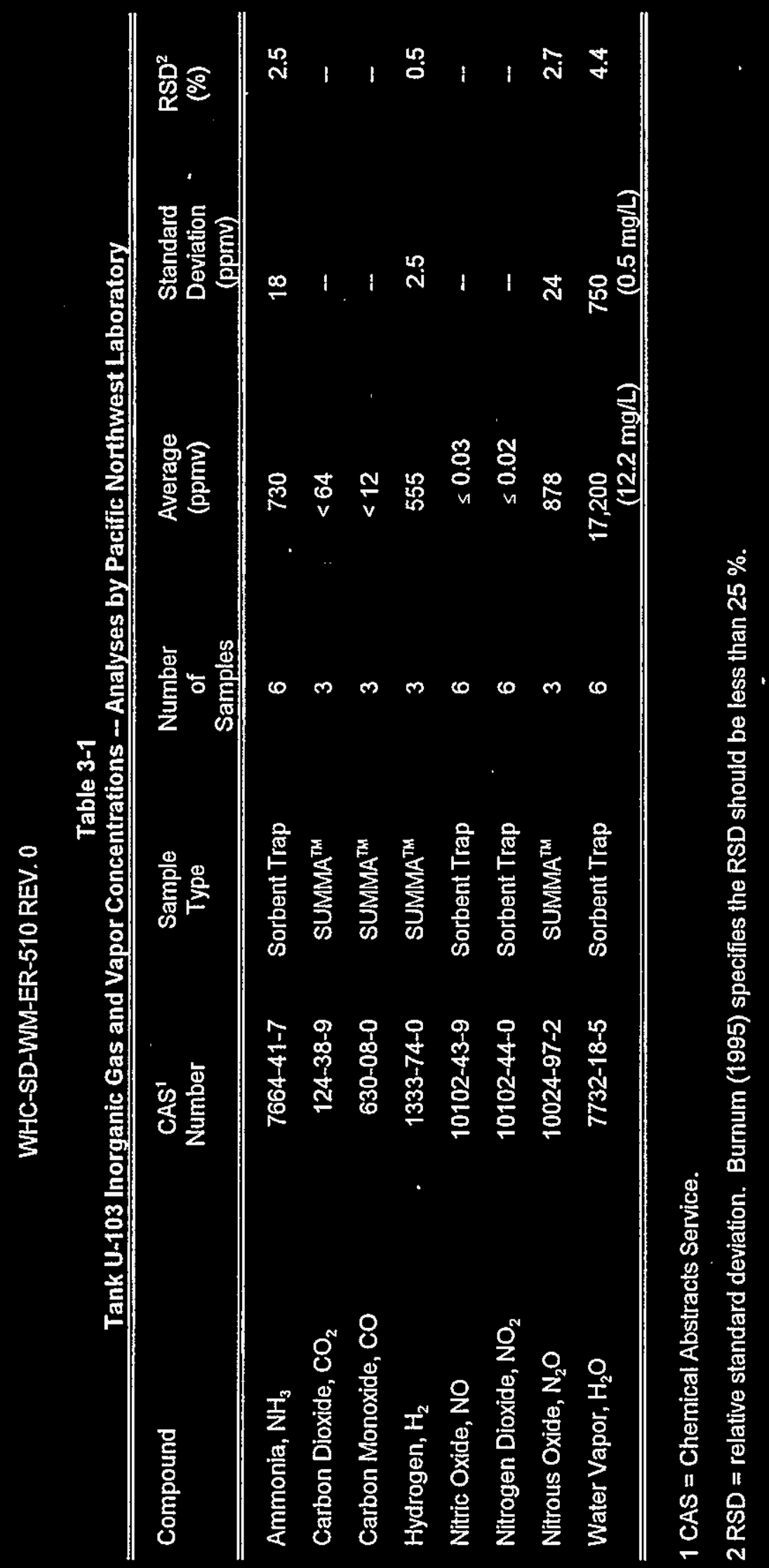


WHC-SD-WM-ER-510 REV. 0

Table 4-1

Tank U-103 Quantitatively Measured Organic Compounds in SUMMA'M Sample Analyses by Pacific Northwest Laboratory

\begin{tabular}{|c|c|c|c|c|c|}
\hline$\underset{\#}{\text { Cmpd }}$ & Compound & $\begin{array}{c}\mathrm{CAS}^{\dagger} \\
\text { Number }\end{array}$ & $\begin{array}{c}\text { Average }^{2} \\
\text { (ppmv) }\end{array}$ & $\begin{array}{c}\text { Standard } \\
\text { Deviation } \\
\text { (ppmv) }\end{array}$ & $\begin{array}{c}\mathrm{RSD}^{3} \\
(\%)\end{array}$ \\
\hline 1 & Ethanenitrile (acetonitrile) & $75-05-8$ & 0.012 & 0.001 & 4 \\
\hline 2 & Propanone (acetone) & $67-64-1$ & 0.17 & 0.03 & 16 \\
\hline 3 & Trichlorofluoromethane & $75-69-4$ & 0.11 & 0.01 & 7 \\
\hline 4 & Propanenitrile & $107-12-0$ & 0.0070 & 0.0013 & 18 \\
\hline 5 & 1-Propanol & $71-23-8$ & 0.034 & 0.013 & 38 \\
\hline 6 & 2-Butanone & $78-93-3$ & 0.0060 & 0.0015 & 25 \\
\hline 7 & Tetrahydrofuran & $109-99-9$ & 0.034 & 0.002 & 5 \\
\hline 8 & Benzene & $71-43-2$ & 0.0053 & 0.0002 & 4 \\
\hline 9 & $\begin{array}{l}\text { Tetrachloromethane (carbon } \\
\text { tetrachloride) }\end{array}$ & $56-23-5$ & 0.0070 & 0.0002 & 3 \\
\hline 10 & Cyclohexane & $110-82-7$ & 0.024 & 0.001 & 3 \\
\hline 11 & Toluene & $108-88-3$ & 0.019 & 0.0004 & 2 \\
\hline 12 & Methane & $74-82-8$ & $<61$ & - & - \\
\hline
\end{tabular}

$1 \mathrm{CAS}=$ Chemical Abstract Service.

2 Average of 3 samples.

$3 \mathrm{RSD}=$ relative standard deviation. Burnum (1995) specities the RSD should be less than $25 \%$. 
WHC-SD-WM-ER-510 REV. 0

Table 4-2

Tank U-103 Quantitatively Measured Organic Compounds in TST Samples Analyses by Oak Ridge National Laboratory ${ }^{1}$

\begin{tabular}{clcccc}
\hline $\begin{array}{c}\text { Cmpd } \\
\#\end{array}$ & Compound & $\begin{array}{c}\text { CAS } \\
\text { Number }\end{array}$ & $\begin{array}{c}\text { Average } \\
\text { (ppmv) }\end{array}$ & $\begin{array}{c}\text { Standard } \\
\text { Deviation } \\
\text { (ppmv) }\end{array}$ & $\begin{array}{c}\mathrm{RSD}^{4} \\
(\%)\end{array}$ \\
\hline \hline 1 & Ethanenitrile (acetonitrile) & $75-05-8$ & 0.16 & 0.01 & 9 \\
2 & Propanone (acetone) & $67-64-1$ & 0.14 & 0.01 & 5 \\
3 & Benzene & $71-43-2$ & 0.011 & 0.0004 & 4 \\
4 & n-Butanenitrile & $109-74-0$ & 0.016 & 0.002 & 13 \\
5 & n-Heptane & $142-82-5$ & 0.0081 & 0.0017 & 21 \\
6 & Toluene & $108-88-3$ & 0.032 & 0.001 & 4 \\
7 & n-Tridecane & $629-50-5$ & 0.0034 & 0.0005 & 15 \\
\hline \hline Sum of positively identified compounds: & & $2.1 \mathrm{mg} / \mathrm{m}^{3}$ & & \\
\hline \hline
\end{tabular}

1 Results in this table are quantitative (as defined in Section 4.1).

$2 \mathrm{CAS}=$ Chemical Abstract Service.

3 Average based on 3, 1-L samples.

4 RSD = relative standard deviation. Burnum (1995) specifies the RSD should be less than $25 \%$. 
WHC-SD-WM-ER-510 REV. 0

Table 4-3

Tank U-103 Positively Identified Organic Compounds in TST Samples Analyses by Oak Ridge National Laboratory ${ }^{1}$

\begin{tabular}{|c|c|c|c|c|c|}
\hline$\underset{\#}{C \operatorname{mpd}}$ & Compound & $\begin{array}{c}\mathrm{CAS}^{2} \\
\text { Number }\end{array}$ & $\begin{array}{c}\text { Average }^{3} \\
\text { (ppmv) }\end{array}$ & $\begin{array}{c}\text { Standard } \\
\text { Deviation } \\
\text { (ppmv) }\end{array}$ & $\begin{array}{c}\mathrm{RSD}^{4} \\
(\%)\end{array}$ \\
\hline 1 & Dichloromethane ${ }^{5}$ (methylene chloride) & $75-09-2$ & 0.017 & - & - \\
\hline 2 & Propanenitrile & $107-12-0$ & 0.0092 & 0.0022 & 24 \\
\hline 3 & $\mathrm{n}$-Hexane & $110-54 m 3$ & 0.0071 & 0.0008 & 12 \\
\hline 4 & n-Pentanenitrile & $110-59-8$ & 0.0013 & 0.0003 & 24 \\
\hline 5 & 2-Hexanone & $591-78-6$ & 0.0026 & 0.0003 & 11 \\
\hline 6 & n-Octane & $111-65-9$ & 0.0027 & 0.0005 & 19 \\
\hline 7 & n-Hexanenitrile & $628-73-9$ & 0.00052 & 0.00008 & 15 \\
\hline 8 & 2-Heptanone & $110-43-0$ & 0.0012 & 0.0002 & 12 \\
\hline 9 & n-Nonane & $111-84-2$ & 0.0016 & 0.0001 & 9 \\
\hline 10 & n-Heptanenitrile & $629-08-3$ & 0.00031 & 0.00002 & 7 \\
\hline 11 & 2-Octanone & $111-13-7$ & 0.00050 & 0.00009 & 18 \\
\hline 12 & n-Decane & $124-18-5$ & 0.0011 & 0.0002 & 15 \\
\hline 13 & n-Undecane & $1120-21-4$ & 0.0013 & 0.0001 & 5 \\
\hline 14 & n-Dodecane & $112-40-3$ & 0.0014 & 0.0002 & .12 \\
\hline \multicolumn{3}{|c|}{ Sum of positively identified compounds: } & $2.1 \mathrm{mg} / \mathrm{m}^{3}$ & & \\
\hline
\end{tabular}

1 Results in this table are not quantitative (as defined in Section 4.1) because measured values in at least 1 of the samples are outside instrument calibration limits.

$2 \mathrm{CAS}=$ Chemical Abstract Service.

3 Average based on $3,1-L$ samples.

$4 \mathrm{RSD}=$ relative standard deviation. Burnum (1995) specifies the RSD should be less than $25 \%$.

5 Dichloromethane was only detected in 2 TST samples. The 2 reported values $(0.0016$ and 0.032 ppmv $)$ had a 181 relative percent difference. 
WHC-SD-WM-ER-510 REV. 0

Table $4-4$

Tank U-103 Positively Identified Compounds in TST Samples

for which Practical Holding Times were Exceeded Analyses by Oak Ridge National Laboratory ${ }^{1}$

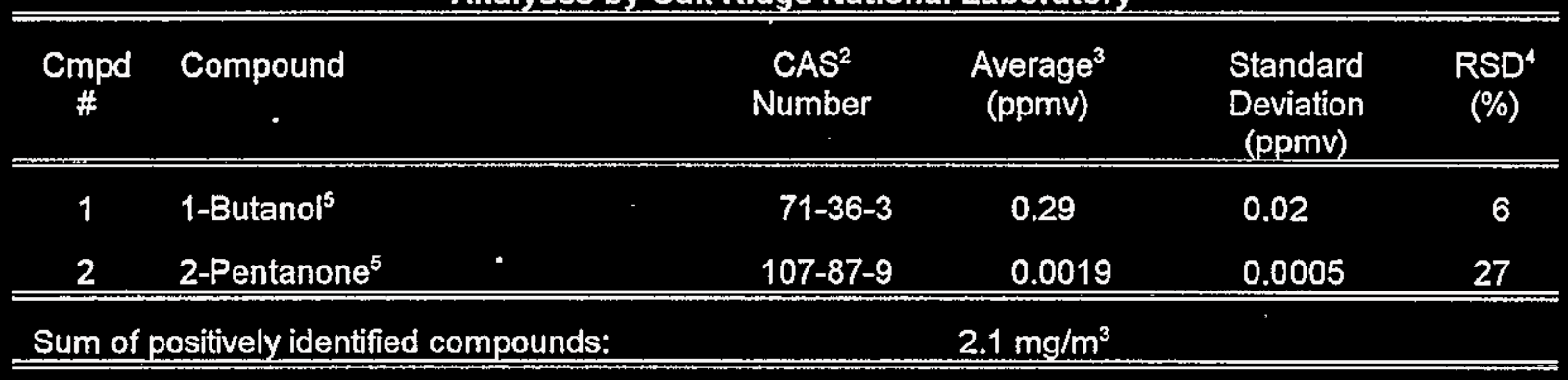

1 Practical holding times are defined and discussed in Section 4.1.

$2 \mathrm{CAS}=$ Chemical Abstract Service.

3 Average based on 3, 1-L samples.

$4 \mathrm{RSD}=$ relative standard deviation, Burnum (1995) specifies the RSD should be less than $25 \%$.

5 The concentration of this analyte was not quantitatively measured (as defined in Section 4.1), because the measured concentration was outside of the instrumental calibration limits. 
WHC-SD-WM-ER-510 REV. 0

Table 4-5

Tank U-103 Comparison of Organic Compounds in TST and SUMMA ${ }^{\text {TM }}$ Samples Analyses by Pacific Northwest Laboratory and Oak Ridge National Laboratory

\begin{tabular}{|c|c|c|c|c|c|}
\hline$\underset{\#}{\text { Cmpd }}$ & Compound & $\begin{array}{c}\text { CAS }^{1} \\
\text { Number }\end{array}$ & $\begin{array}{c}\text { TST }^{2} \\
\text { Average } \\
\text { (ppmv) }\end{array}$ & $\begin{array}{l}\text { SUMMA }^{\text {TM }} \\
\text { Average }^{3} \\
\text { (ppmv) } \\
\end{array}$ & $\begin{array}{c}\mathrm{PRD}^{4} \\
(\%)\end{array}$ \\
\hline 1 & $\begin{array}{l}\text { 1,1-Dichloroethene } \\
\text { (vinylidene chloride) }\end{array}$ & $75-35-4$ & $<0.0023$ & $<0.005$ & - \\
\hline 2 & $\begin{array}{l}\text { Dichloromethane } \\
\text { (methylene chloride) }\end{array}$ & $75-09-2$ & 0.017 & $<0.005$ & $>109$ \\
\hline 3 & Propanone (acetone) & $67-64-1$ & 0.14 & 0.17 & 19 \\
\hline 4 & Ethanenitrile (acetonitrile) & $75-05-8$ & 0.16 & 0.012 & 172 \\
\hline 5 & Propanenitrile & $107-12-0$ & 0.0092 & 0.007 & 27 \\
\hline 6 & n-Butanenitrile & $109-74-0$ & 0.016 & $<0.005$ & $>105$ \\
\hline 7 & Benzene & $71-43-2$ & 0.011 & 0.0053 & 70 \\
\hline 8 & Toluene & $108-88-3$ & 0.032 & 0.019 & 51 \\
\hline 9 & n-Hexane & $110-54-3$ & 0.0071 & $<0.005$ & $>35$ \\
\hline 10 & n-Heptane & $142-82-5$ & 0.0081 & $<0.005$ & $>47$ \\
\hline 11 & n-Decane & $124-18-5$ & 0.0011 & $<0.005$ & - \\
\hline
\end{tabular}

$1 \mathrm{CAS}=$ Chemical Abstract Service.

2 Analyses of 3, 1-L samples conducted by ORNL.

3 Analyses of 3 samples conducted by PNL.

$4 \mathrm{PRD}=$ percent relative difference. Keiler (1994) requires the PRD to be less than $20 \%$. 
WHC-SD-WM-ER-510 REV. 0

Table 4-6

Tank U-103 Tentatively ldentified Organic Compounds in SUMMA'M Samples -Analyses by Pacific Northwest Laboratories

\begin{tabular}{|c|c|c|c|c|}
\hline$\underset{\#}{\text { Cmpd }}$ & Compounds & $\begin{array}{c}\mathrm{CAS}^{1} \\
\text { Number }\end{array}$ & $\begin{array}{l}\text { Average } \\
\left(\mathrm{mg} / \mathrm{m}^{3}\right)\end{array}$ & $\begin{array}{c}\text { Standard } \\
\text { Deviation }{ }^{2} \\
\left(\mathrm{mg} / \mathrm{m}^{3}\right)\end{array}$ \\
\hline 1 & Methyl Alcohol & $67-56-1$ & 3.15 & 0.28 \\
\hline 2 & Ethanol $^{3}$ & $64-17-5$ & 2.26 & - \\
\hline 3 & 1-Butanol ${ }^{3}$ & $71-36-3$ & 0.75 & 0.06 \\
\hline 4 & 1-Butene & $106-98-9$ & 0.72 & 0.04 \\
\hline 5 & Unknown Alkane & & 0.60 & $0.39^{\prime}$ \\
\hline 6 & n-Butane & $106-97-8$ & 0.50 & 0.20 \\
\hline 7 & Propene & $115-07-1$ & 0.36 & 0.02 \\
\hline 8 & Propane & $74-98-6$ & 0.36 & 0.03 \\
\hline 9 & Cyclopropane & $75-19-4$ & 0.19 & 0.04 \\
\hline 10 & Dimethyl ether & $115-10-6$ & 0.17 & 0.08 \\
\hline 11 & n-Pentane ${ }^{4}$ & $109-66-0$ & 0.13 & - \\
\hline 12 & Unknown C4 Alkene/Cycloalkane ${ }^{4}$ & & 0.13 & 0.01 \\
\hline 13 & N-Nitrosodimethylamine ${ }^{3}$ & $62-75-9$ & 0.045 & 0.005 \\
\hline 14 & Acetaldehyde & $75-07-0$ & $<0.02$ & - \\
\hline 15 & 2-Butanone & $78-93-3$ & $<0.03$ & - \\
\hline \multicolumn{2}{|c|}{ Sum of tentatively identified compounds: } & & 9.4 & \\
\hline
\end{tabular}

$1 \mathrm{CAS}=$ Chemical Abstract Service.

2 When the analyte was detected in only 2 samples, the entry is the relative difference (i.e., their difference divided by 2).

3 Detected in only 1 sample.

4 Detected in only 2 samples.

5 Average of 3 samples, presented values are estimates. 
WHC-SD-WM-ER-510 REV. 0

Table 4-7

Tank U-103 Tentatively Identified Organic Compounds in TST Samples in Order of Chromatographic Elution -

Analyses by Oak Ridge National Laboratory

\begin{tabular}{|c|c|c|c|c|}
\hline$\underset{\#}{\text { Cmpd }}$ & Compounds & $\begin{array}{l}\mathrm{CAS}^{1} \\
\text { Number }\end{array}$ & $\begin{array}{c}\text { Average } \\
\left(\mathrm{mg} / \mathrm{m}^{3}\right)\end{array}$ & $\begin{array}{c}\text { Standard } \\
\text { Deviation } \\
\left(\mathrm{mg} / \mathrm{m}^{3}\right)\end{array}$ \\
\hline 1 & Carbon Dioxide & $124-38-9$ & 0.44 & $\quad 0.39$ \\
\hline 2 & 1-Propene, 2-methyl- & $115-11-7$ & 0.016 & 0.027 \\
\hline 3 & Methyl Alcohol & $67-56-1$ & 0.94 & 0.54 \\
\hline 4 & 1-Propene, 2-methyl- & $115-11-7$ & 0.0044 & 0.0076 \\
\hline 5 & Methane, dichlorofluoro- & $75-43-4$ & 0.0081 & 0.0140 \\
\hline 6 & Ethanol & $64-17-5$ & 1.26 & 0.15 \\
\hline 7 & Trichioromonofluoromethane & $75-69-4$ & 0.68 & 0.41 \\
\hline 8 & Isopropyl Alcohol & $67-63-0$ & 0.19 & 0.07 \\
\hline 9 & $\begin{array}{l}\text { 2-Propenenitrile and } \\
\text { 2,2-dimethylbutane }\end{array}$ & & 0.027 & 0.001 \\
\hline 10 & Pentane, 2-methyl- & $107-83-5$ & 0.033 & 0.004 \\
\hline 11 & 1-Propanol & $71-23-8$ & 0.098 & 0.008 \\
\hline 12 & 1-Butanol, 2-methyl- & $137-32-6$ & 0.015 & 0.013 \\
\hline 13 & Cyclobutanol and others & & 0.0059 & 0.0102 \\
\hline 14 & Furan, tetrahydro- & $109-99-9$ & 0.080 & 0.004 \\
\hline 15 & 2-Propanone, 1,1,1-trifluoro- & $421-50-1$ & 0.017 & $\cdot 0.030$ \\
\hline 16 & 1-Propanol, 2-methyl & $78-83-1$ & 0.0054 & 0.0093 \\
\hline 17 & Acetic acid, methyl ester & $79-20-9$ & 0.047 & 0.081 \\
\hline 18 & 1,2,3,6-tetrahydropyridine & $694-05-3$ & 0.013 & 0.011 \\
\hline 19 & 1,4-Dioxane & $123-91-1$ & 0.018 & 0.006 \\
\hline 20 & Pyrazine & $290-37-9$ & 0.19 & 0.01 \\
\hline 21 & Methyl Isobutyl Ketone & $108-10-1$ & 0.028 & 0.004 \\
\hline 22 & Propane, 2-methyl-2-nitro- & $594-70-7$ & 0.032 & 0.005 \\
\hline 23 & N-Nitrosodimethyl-amine & $62-75-9$ & 0.21 & 0.02 \\
\hline 24 & Formamide and others & & 0.019 & 0.017 \\
\hline 25 & Heptane, 3-methyl- & $589-81-1$ & 0.0037 & 0.0064 \\
\hline 26 & 1H-1,2,4-Triazole & $288-88-0$ & 0.0089 & 0.0154 \\
\hline
\end{tabular}


WHC-SD-WM-ER-510 REV. 0

\begin{tabular}{|c|c|c|c|c|}
\hline$\underset{\#}{C \text { Cmpd }}$ & Compounds & $\begin{array}{l}\text { CAS }^{1} \\
\text { Number }\end{array}$ & $\begin{array}{l}\text { Average } \\
\left(\mathrm{mg} / \mathrm{m}^{3}\right)\end{array}$ & $\begin{array}{c}\text { Standard } \\
\text { Deviation } \\
\left(\mathrm{mg} / \mathrm{m}^{3}\right)\end{array}$ \\
\hline 27 & 1-Octene & $111-66-0$ & 0.0048 & 0.0083 \\
\hline 28 & Cyclopropane, (1-methylethyl)- & $3638-35-5$ & 0.033 & 0.029 \\
\hline 29 & Tetrachloroethylene & $127-18-4$ & 0.022 & 0.001 \\
\hline 30 & Cyclotrisiloxane, hexamethyl & $541-05-9$ & 0.023 & 0.030 \\
\hline 31 & Pyrazine, methyl- & $109-08-0$ & 0.014 & 0.002 \\
\hline 32 & Oxazole, 4,5-dihydro-2-methyl- & $1120-64-5$ & 0.026 & 0.007 \\
\hline 33 & Ethylbenzene & $100-41-4$ & 0.020 & 0.002 \\
\hline 34 & p-Xylene & $106-42-3$ & 0.067 & 0.005 \\
\hline 35 & Pyridine, 3-methyl- & $108-99-6$ & 0.0057 & 0.0098 \\
\hline 36 & 3-Heptanone & $106-35-4$ & 0.019 & 0.002 \\
\hline 37 & p-Xylene & $106-42-3$ & 0.029 & 0.002 \\
\hline 38 & Pyrazine, ethyl- & $13925-00-3$ & 0.0078 & 0.0069 \\
\hline 39 & 3-Hexenal, (Z)- & $6789-80-6$ & 0.021 & 0.003 \\
\hline 40 & Cyclohexane, octyl & $1795-15-9$ & 0.013 & 0.002 \\
\hline 41 & 2-Hexenoic acid, 4-methylphenyl ester & $69687-91-8$ & 0.013 & 0.002 \\
\hline 42 & 2-Heptanone, 6-methyl- & $928-68-7$ & 0.0034 & 0.0060 \\
\hline 43 & 1-Decene & $872-05-9$ & 0.044 & 0.005 \\
\hline 44 & $\begin{array}{l}\text { Phenol and cyclotetrasiloxane, } \\
\text { octamethyl }\end{array}$ & & 0.023 & 0.011 \\
\hline 45 & Benzene, tert-butyl- & $98-06-6$ & 0.024 & 0.002 \\
\hline 46 & 1-Heptanol & $111-70-6$ & 0.011 & 0.002 \\
\hline 47 & 1-Hexanol, 2-ethyl- & $104-76-7$ & 0.014 & 0.002 \\
\hline 48 & Nonanenitrile & $2243-27-8$ & 0.0081 & 0.0078 \\
\hline 49 & 1H-Pyrazole, 4,5- dihydro-5-propyl- & $75011-90-4$ & 0.0076 & 0.0131 \\
\hline 50 & Oxazole, 4,5- dimethyl-2-propyl- & $53833-32-2$ & 0.033 & 0.003 \\
\hline 51 & Formamide, $n$-butyl and others & & 0.019 & 0.009 \\
\hline 52 & Benzyl Alcohol & $100-51-6$ & 0.0078 & 0.0136 \\
\hline 53 & alkyl nitrile & & 0.0034 & 0.0059 \\
\hline 54 & Acetophenone & $98-86-2$ & 0.0058 & 0.0051 \\
\hline
\end{tabular}


WHC-SD-WM-ER-510 REV. 0

\begin{tabular}{clccc}
\hline \hline $\begin{array}{c}\text { Cmpd } \\
\#\end{array}$ & Compounds & $\begin{array}{c}\text { CAS }^{1} \\
\text { Number }\end{array}$ & $\begin{array}{c}\text { Average } \\
\left(\mathrm{mg} / \mathrm{m}^{3}\right)\end{array}$ & $\begin{array}{c}\text { Standard } \\
\text { Deviation } \\
\left(\mathrm{mg} / \mathrm{m}^{3}\right)\end{array}$ \\
\hline 55 & $4(1 \mathrm{H})$-Pyrimidinone and others & & 0.0022 & 0.0039 \\
56 & Undecane, 4,4-dimethyl- & $17312-68-4$ & 0.024 & 0.003 \\
57 & Naphthalene and others & & 0.010 & 0.001 \\
58 & 2-Oxazolidinone, 5-methyl-3- & $55956-20-2$ & 0.020 & 0.003 \\
59 & (2-propenyl)- & $17312-62-8$ & 0.0024 & 0.0041 \\
60 & Decane, 5-propyl- & $74645-98-0$ & 0.0047 & 0.0041 \\
61 & Tetradecane & $629-59-4$ & 0.012 & 0.001 \\
62 & Hexadecanoic acid & $57-10-3$ & 0.0056 & 0.0051 \\
63 & Tetradecanoic acid , & $544-63-8$ & 0.0073 & 0.0127 \\
64 & Benzenesulfonamide, N-butyl & $3622-84-2$ & 0.045 & 0.008 \\
65 & Isopropyl Palmitate & $142-91-6$ & 0.031 & 0.029 \\
\hline \hline Sum of tentatively identified compounds: & & 5.07 & \\
\hline \hline
\end{tabular}

$1 \mathrm{CAS}=$ Chemical Abstract Service.

2 Average based on 3, 1-L samples, presented values are estimates. 
WHC-SD-WM-ER-510 REV. 0

Table 4-8

Tank U-103 Tentatively Identified Organic Compounds in TST Samples Sorted Alphanumerically Analyses by Oak Ridge National Laboratories

\begin{tabular}{|c|c|c|c|c|}
\hline$\underset{\#}{\text { Cmpd }}$ & Compounds & $\begin{array}{l}\text { CAS }^{1} \\
\text { Number }\end{array}$ & $\begin{array}{l}\text { Average }{ }^{2} \\
\left(\mathrm{mg} / \mathrm{m}^{3}\right)\end{array}$ & $\begin{array}{c}\text { Standard } \\
\text { Deviation } \\
\left(\mathrm{mg} / \mathrm{m}^{3}\right) \\
\end{array}$ \\
\hline 43 & 1-Decene & $872-05-9$ & 0.044 & 0.005 \\
\hline 2 & 1-Propene, 2-methyi- & $115-11-7$ & 0.016 & 0.027 \\
\hline 27 & 1-Octene & $111-66-0$ & 0.0048 & 0.0083 \\
\hline 4 & 1-Propene, 2-methyl- & $115-11-7$ & 0.0044 & 0.0076 \\
\hline 46 & 1-Heptanol & $111-70-6$ & 0.011 & 0.002 \\
\hline 16 & 1-Propanol, 2-methyl & $78-83-1$ & 0.0054 & 0.0093 \\
\hline 47 & 1-Hexanol, 2-ethyl- & $104-76-7$ & 0.014 & 0.002 \\
\hline 12 & 1-Butanol, 2-methyl- & $137-32-6$ & 0.015 & 0.013 \\
\hline 11 & 1-Propanol & $71-23-8$ & 0.098 & 0.008 \\
\hline 19 & 1,4-Dioxane & $123-91-1$ & 0.018 & 0.006 \\
\hline 18 & 1,2,3,6-tetrahydro-pyridine & $694-05-3$ & 0.013 & 0.011 \\
\hline 26 & 1H-1,2,4-Triazole & $288-88-0$ & 0.0089 & 0.0154 \\
\hline 49 & 1H-Pyrazole, 4,5- dihydro-5-propyl- & $75011-90-4$ & 0.0076 & 0.0131 \\
\hline 41 & 2-Hexenoic acid, 4-methylphenyl ester & $69687-91-8$ & 0.013 & 0.002 \\
\hline 15 & 2-Propanone, 1,1,1-trifluoro- & $421-50-1$ & 0.017 & 0.030 \\
\hline 42 & 2-Heptanone, 6-methyl- & $928-68-7$ & 0.0034 & 0.0060 \\
\hline 58 & $\begin{array}{l}\text { 2-Oxazolidinone, } \\
\text { 5-methyl-3-(2-propenyl)- }\end{array}$ & $55956-20-2$ & 0.020 & 0.003 \\
\hline 9 & $\begin{array}{l}\text { 2-Propenenitrile and } \\
\text { 2,2-dimethylbutane }\end{array}$ & & 0.027 & 0.001 \\
\hline 36 & 3-Heptanone & $106-35-4$ & 0.019 & 0.002 \\
\hline 39 & 3-Hexenal, (Z)- & $6789-80-6$ & 0.021 & 0.003 \\
\hline 55 & $4(1 \mathrm{H})$-Pyrimidinone and others & & 0.0022 & 0.0039 \\
\hline 17 & Acetic acid, methyl ester & $79-20-9$ & 0.047 & 0.081 \\
\hline 54 & Acetophenone & $98-86-2$ & 0.0058 & 0.0051 \\
\hline 53 & alkyl nitrile & & 0.0034 & 0.0059 \\
\hline 45 & Benzene, tert-butyl- & $98-06-6$ & 0.024 & 0.002 \\
\hline
\end{tabular}


WHC-SD-WM-ER-510 REV. 0

\begin{tabular}{|c|c|c|c|c|}
\hline$\underset{\#}{C \text { Cmpd }}$ & Compounds & $\begin{array}{l}\text { CAS }^{1} \\
\text { Number }\end{array}$ & $\begin{array}{c}\text { Average }^{2} \\
\left(\mathrm{mg} / \mathrm{m}^{3}\right)\end{array}$ & $\begin{array}{l}\text { Standard } \\
\text { Deviation } \\
\left(\mathrm{mg} / \mathrm{m}^{3}\right)\end{array}$ \\
\hline 64 & Benzenesulfonamide, $\mathrm{N}$-butyl & $3622-84-2$ & 0.045 & 0.008 \\
\hline 52 & Benzyl Alcohol & $100-51-6$ & 0.0078 & 0.0136 \\
\hline 1 & Carbon Dioxide & $124-38-9$ & 0.44 & 0.39 \\
\hline 13 & Cyclobutanol and others & & 0.0059 & 0.0102 \\
\hline 40 & Cyclohexane, octyl & $1795-15-9$ & 0.013 & 0.002 \\
\hline 28 & Cyclopropane, (1-methylethyl)- & $3638-35-5$ & 0.033 & 0.029 \\
\hline 30 & Cyclotrisiloxane, hexamethyl & $541-05-9$ & 0.023 & 0.030 \\
\hline 59 & Decane, 5-propyl- & $17312-62-8$ & 0.0024 & 0.0041 \\
\hline 60 & Dodecane, 2,7,10-trimethyl- & $74645-98-0$ & 0.0047 & 0.0041 \\
\hline 6 & Ethanol & $64-17-5$ & 1.26 & 0.15 \\
\hline 33 & Ethyibenzene & $100-41-4$ & 0.020 & 0.002 \\
\hline 24 & Formamide and others & & 0.019 & 0.017 \\
\hline 51 & Formamide, $n$-butyl and others & & 0.019 & 0.009 \\
\hline 14 & Furan, tetrahydro. & $109-99-9$ & 0.080 & 0.004 \\
\hline 25 & Heptane, 3-methyl- & $589-81-1$ & 0.0037 & 0.0064 \\
\hline 62 & Hexadecanoic acid & $57-10-3$ & 0.0056 & 0.0051 \\
\hline 8 & Isopropyl Alcohol & $67-63-0$ & 0.19 & 0.07 \\
\hline 65 & Isopropyl Palmitate & $142-91-6$ & 0.031 & 0.029 \\
\hline 5 & Methane, dichlorofluoro- & $75-43-4$ & 0.0081 & 0.0140 \\
\hline 3 & Methyl Alcohol & $67-56-1$ & 0.94 & 0.54 \\
\hline 21 & Methyl Isobutyi Ketone & $108-10-1$ & 0.028 & 0.004 \\
\hline 23 & N-Nitrosodimethyl-amine & $62-75-9$ & 0.21 & 0.02 \\
\hline 57 & Naphthalene and others & & 0.010 & 0.001 \\
\hline 48 & Nonanenitrile & $2243-27-8$ & 0.0081 & 0.0078 \\
\hline 32 & Oxazole, 4,5-dihydro-2-methyl- & $1120-64-5$ & 0.026 & 0.007 \\
\hline 50 & Oxazole, 4,5- dimethyl-2-propyl- & $53833-32-2$ & 0.033 & 0.003 \\
\hline 34 & p-Xylene & $106-42-3$ & 0.067 & 0.005 \\
\hline 37 & p-Xylene & $.106-42-3$ & 0.029 & 0.002 \\
\hline 10 & Pentane, 2-methyl- & $107-83-5$ & 0.033 & 0.004 \\
\hline
\end{tabular}


WHC-SD-WM-ER-510 REV. 0

\begin{tabular}{clccc}
\hline $\begin{array}{c}\text { Cmpd } \\
\#\end{array}$ & Compounds & $\begin{array}{c}\text { CAS } \\
\text { Number }\end{array}$ & $\begin{array}{c}\text { Average } \\
\left(\mathrm{mg}^{2} \mathrm{~m}^{3}\right)\end{array}$ & $\begin{array}{c}\text { Standard } \\
\text { Deviation } \\
\left(\mathrm{mg}^{3} \mathrm{~m}^{3}\right)\end{array}$ \\
\hline 44 & $\begin{array}{l}\text { Phenol and cyclotetrasiloxane, } \\
\text { octamethyl }\end{array}$ & 0.023 & 0.011 \\
22. & Propane, 2-methyl-2-nitro- & $594-70-7$ & 0.032 & 0.005 \\
20 & Pyrazine & $290-37-9$ & 0.19 & 0.01 \\
31 & Pyrazine, methyl- & $109-08-0$ & 0.014 & 0.002 \\
38 & Pyrazine, ethyl- & $13925-00-3$ & 0.0078 & 0.0069 \\
35 & Pyridine, 3-methyl- & $108-99-6$ & 0.0057 & 0.0098 \\
29 & Tetrachloroethylene & $127-18-4$ & 0.022 & 0.001 \\
61 & Tetradecane & $629-59-4$ & 0.012 & 0.001 \\
63 & Tetradecanoic acid & $544-63-8$ & 0.0073 & 0.0127 \\
7 & Trichloromonofluoromethane & $75-69-4$ & 0.68 & 0.41 \\
56 & Undecane, 4,4-dimethyl- & $17312-68-4$ & 0.024 & 0.003 \\
\hline \hline Sum of tentatively identified compounds: & & 5.07 & \\
\hline \hline
\end{tabular}

$1 \mathrm{CAS}=$ Chemical Abstract Service.

2 Average based on 3, 1-i samples, presented values are estimates. 
Table 4-9

Tank U-103 Tentatively Identified Organic Compounds in TST Samples -Sorted by Estimated Concentration Analyses by Oak Ridge National Laboratory.

\begin{tabular}{|c|c|c|c|c|}
\hline Cmpd & Compounds & $\begin{array}{l}\text { CAS }^{\dagger} \\
\text { Number }\end{array}$ & $\begin{array}{l}\text { Average }^{2} \\
\left(\mathrm{mg} / \mathrm{m}^{3}\right)\end{array}$ & $\begin{array}{c}\text { Standard } \\
\text { Deviation } \\
\left(\mathrm{mg} / \mathrm{m}^{3}\right)\end{array}$ \\
\hline 6 & Ethanol & $64-17-5$ & 1.26 & 0.15 \\
\hline 3 & Methyl Alcohol & $67-56-1$ & 0.94 & 0.54 \\
\hline 7 & Trichloromonofluoromethane & $75-69-4$ & 0.68 & 0.41 \\
\hline 1 & Carbon Dioxide & $124-38-9$ & 0.44 & 0.39 \\
\hline 23 & N-Nitrosodimethyl-amine & $62-75-9$ & 0.21 & 0.02 \\
\hline 20 & Pyrazine & $290-37-9$ & 0.19 & 0.01 \\
\hline 8 & Isopropy| Alcohol & $67-63-0$ & 0.19 & 0.07 \\
\hline 11 & 1-Propanol & $71-23-8$ & 0.098 & 0.008 \\
\hline 14 & Furan, tetrahydro- & $109-99-9$ & 0.080 & 0.004 \\
\hline 34 & p-Xylene & $1006-42-3$ & 0.067 & 0.005 \\
\hline 17 & Acetic acid, methyl ester & $79-20-9$ & 0.047 & 0.081 \\
\hline 64 & Benzenesulfonamide, N-buty! & $3622-84-2$ & 0.045 & 0.008 \\
\hline 43 & 1-Decene & $872-05-9$ & 0.044 & 0.005 \\
\hline 10 & Pentane, 2-methyl- & $107-83-5$ & 0.033 & 0.004 \\
\hline 28 & Cyclopropane, (1-methylethyl)- & $3638-35-5$ & 0.033 & 0.029 \\
\hline 50 & Oxazole, 4,5- dimethyl-2-propyl- & $53833-32-2$ & 0.033 & 0.003 \\
\hline 22 & Propane, 2-methyl-2-nitro- & $594-70-7$ & 0.032 & 0.005 \\
\hline 65 & Isopropyl Palmitate & $142-91-6$ & 0.031 & 0.029 \\
\hline 37 & p-Xylene & $106-42-3$ & 0.029 & 0.002 \\
\hline 21 & Methyl Isobutyl Ketone & $108-10-1$ & 0.028 & 0.004 \\
\hline 9 & $\begin{array}{l}\text { 2-Propenenitrile and } \\
\text { 2,2-dimethylbutane }\end{array}$ & & 0.027 & 0.001 \\
\hline 32 & Oxazole, 4,5- dihydro-2-methyl- & $1120-64-5$ & 0.026 & 0.007 \\
\hline 56 & Undecane, 4,4-dimethyl- & $17312-68-4$ & 0.024 & 0.003 \\
\hline 45 & Benzene, tert-butyl- & $98-06-6$ & 0.024 & 0.002 \\
\hline 44 & $\begin{array}{l}\text { Phenol and cyclotetrasiloxane, } \\
\text { octamethyl }\end{array}$ & & 0.023 & 0.011 \\
\hline
\end{tabular}


WHC-SD-WM-ER-510 REV. 0

\begin{tabular}{|c|c|c|c|c|}
\hline$\underset{\#}{\text { Cmpd }}$ & Compounds & $\begin{array}{c}\text { CAS }^{1} \\
\text { Number }\end{array}$ & $\begin{array}{c}\text { Average } \\
\left(\mathrm{mg} / \mathrm{m}^{3}\right)\end{array}$ & $\begin{array}{c}\text { Standard } \\
\text { Deviation } \\
\left(\mathrm{mg} / \mathrm{m}^{3}\right)\end{array}$ \\
\hline 30 & Cyclotrisiloxane, hexamethyl & $541-05-9$ & 0.023 & 0.030 \\
\hline 29 & Tetrachloroethylene & $127-18-4$ & 0.022 & 0.001 \\
\hline 39 & 3-Hexenal, (Z)- & $6789-80-6$ & 0.021 & 0.003 \\
\hline 58 & $\begin{array}{l}\text { 2-Oxazolidinone, 5-methyl-3- } \\
\text { (2-propenyl)- }\end{array}$ & $.55956-20-2$ & 0.020 & 0.003 \\
\hline 33 & Ethylbenzene & $100-41-4$ & 0.020 & 0.002 \\
\hline 24 & Formamide and others & & 0.019 & 0.017 \\
\hline 36 & 3-Heptanone & $106-35-4$ & 0.019 & 0.002 \\
\hline 51 & Formamide, n-butyl and others & & 0.019 & 0.009 \\
\hline 19 & 1,4-Dioxane & $123-91-1$ & 0.018 & 0.006 \\
\hline 15 & 2-Propanone, 1,1,1-trifluoro- & $421-50-1$ & 0.017 & 0.030 \\
\hline 2 & 1-Propene, 2-methyi- & $115-11-7$ & 0.016 & 0.027 \\
\hline 12 & 1-Butanol, 2-methyl- & $137-32-6$ & 0.015 & 0.013 \\
\hline 31 & Pyrazine, methyl- & $109 m 08 m 0$ & 0.014 & 0.002 \\
\hline 47 & 1-Hexanol, 2-ethyl- & $104-76-7$ & 0.014 & 0.002 \\
\hline 40 & Cyclohexane, octyl & $1795-15-9$ & 0.013 & 0.002 \\
\hline 41 & 2-Hexenoic acid, 4-methyiphenyl ester & $69687-91-8$ & 0.013 & 0.002 \\
\hline 18 & 1,2,3,6-tetrahydro-pyridine & $694-05-3$ & 0.013 & 0.011 \\
\hline 61 & Tetradecane & $629-59-4$ & 0.012 & 0.001 \\
\hline 46 & 1-Heptanol & $111-70-6$ & 0.011 & 0.002 \\
\hline 57 & Naphthalene and others & & 0.010 & 0.001 \\
\hline 26 & 1H-1,2,4-Triazole & $288-88-0$ & 0.0089 & 0.0154 \\
\hline 5 & Methane, dichlorofluoro- & $75-43-4$ & 0.0081 & 0.0140 \\
\hline 48 & Nonanenitrile & $2243-27-8$ & 0.0081 & 0.0078 \\
\hline 38 & Pyrazine, ethyl- & $13925-00-3$ & 0.0078 & 0.0069 \\
\hline 52 & Benzyl Alcohol & $100-51-6$ & 0.0078 & 0.0136 \\
\hline 49 & 1H-Pyrazole, 4,5- dihydro-5-propyl- & $75011-90-4$ & 0.0076 & 0.0131 \\
\hline 63 & Tetradecanoic acid & $544-63-8$ & 0.0073 & 0.0127 \\
\hline 13 & Cyclobutanol and others & & 0.0059 & 0.0102 \\
\hline
\end{tabular}


WHC-SD-WM-ER-510 REV. 0

\begin{tabular}{clrrr}
\hline $\begin{array}{c}\text { Cmpd } \\
\#\end{array}$ & Compounds & $\begin{array}{c}\text { CAS } \\
\text { Number }\end{array}$ & $\begin{array}{c}\text { Average } \\
\left(\mathrm{mg}^{2} / \mathrm{m}^{3}\right)\end{array}$ & $\begin{array}{c}\text { Standard } \\
\text { Deviation } \\
\left(\mathrm{mg} / \mathrm{m}^{3}\right)\end{array}$ \\
\hline 54 & Acetophenone & $98-86-2$ & 0.0058 & 0.0051 \\
35 & Pyridine, 3-methyl- & $108-99-6$ & 0.0057 & 0.0098 \\
62 & Hexadecanoic acid & $57-10-3$ & 0.0056 & 0.0051 \\
16 & 1-Propanol, 2-methyl & $78-83-1$ & 0.0054 & 0.0093 \\
27 & 1-Octene & $111-66-0$ & 0.0048 & 0.0083 \\
60 & Dodecane, 2,7,10-trimethyl- & $74645-98-0$ & 0.0047 & 0.0041 \\
4 & 1-Propene, 2-methyl- & $115-11-7$ & 0.0044 & 0.0076 \\
25 & Heptane, 3-methyl- & $589-81-1$ & 0.0037 & 0.0064 \\
53 & alkyl nitrile & & 0.0034 & 0.0059 \\
42 & 2-Heptanone, 6-methyl- & $-928-68-7$ & 0.0034 & 0.0060 \\
59 & Decane, 5-propyl- & $17312-62-8$ & 0.0024 & 0.0041 \\
55 & 4(1H)-Pyrimidinone and others & $\cdot$ & 0.0022 & 0.0039 \\
\hline \hline Sum of tentatively identified compounds: & & 5.07 & \\
\hline \hline
\end{tabular}

$1 \mathrm{CAS}=$ Chemical Abstract Service

2 Average based on 3, 1- $L$ samples, presented values are estimates. 
